\title{
CENSURA EDITORIAL Y CRÍTICA LITERARIA DURANTE EL FRANQUISMO. EL CASO DE ANTONIO IGLESIAS LAGUNA
}

Book Censorship and Literary Criticism during Francoism. The Case of Antonio Iglesias Laguna

\author{
MARÍA ÁlVAREZ VILLALOBOS \\ UNIVERSIDAD DE ALCALÁ (ESPAÑA) \\ marialvarezvillalobos96@gmail.com http://orcid.org/0000-0001-7611-1047
}

RECIBIDO: 15 DE MAYO DE 2019

ACEPTADO: 16 DE ABRIL DE 2020

RESUMEN: El objetivo principal de este trabajo es analizar la interacción entre los discursos sobre textos narrativos hallados en los informes de censura y los de la crítica literaria en prensa, así como las relaciones entre ambas durante el último periodo del franquismo. Intentaremos establecer la correlación entre dos vías distintas que perseguían fortalecer un discurso literario oficial y subsidiario de intereses políticos. Para ello, se ha tomado el caso de Antonio Iglesias Laguna, crítico literario y censor durante este periodo, prestando especial atención a la etapa posterior a la publicación de la ley de Prensa e Imprenta de 1966. Con este propósito, se han recopilado, analizado y cotejado las críticas literarias en $A B C$ y La Estafeta Literaria entre 1964 y 1972 que se correspondían con textos que aparecían publicados por primera vez en España, sus informes como lector de la censura entre 1967 y 1972 así como de su ensayo Treinta años de novela española (1938-1968) (1969).

PAlabras ClaVE: Crítica literaria, censura, Antonio Iglesias Laguna, canon, La Estafeta Literaria.

ABSTRACT: The main objective of this paper is to analyse the interaction between the discourses on narrative texts found in censorship files and those of press literary criticism as well as the relations between both of them in the last period of Francoism. We will try to set the correlation between two different procedures that sought to strengthen an official literary discourse under political interests. Thus, we have taken the case of Antonio Iglesias Laguna, literary critic and censor during this period, focusing on the period after the Press and Printing Law (1966). With this purpose, we have compiled, analyzed and collated his literary critics in $A B C$ and La Estafeta Literaria between 1964 and 1972, his reports as a reader of censorship between 1967 and 1972 and his essay Treinta años de novela española (1938-1968) (1969).

KEYWORDS: Literary Criticism, Censorship, Antonio Iglesias Laguna, canon, La Estafeta Literaria. 


\section{INTRODUCCIÓN}

Cualquier acercamiento desde la crítica y la historiografía literarias al estudio de las obras entre 1936 y 1976 tiene que tener en cuenta la censura como condicionamiento y elemento explicativo fundamental. Desde los años ochenta han ido proliferando estudios ${ }^{1}$ que se acercan al análisis de la censura editorial franquista desde el campo de la sociología cultural y la historia. Manuel L. Abellán fue el investigador pionero en el campo (Abellán, 1980) cuando todavía el acceso a los archivos estaba muy restringido y la información pública sobre el funcionamiento de la censura era casi inexistente. Los estudios sobre la censura, sin embargo, dejan todavía aspectos sin resolver. No se conoce la nómina completa de los censores que trabajaron para la Administración, las obras que se publican en la actualidad en muchos casos siguen sin reparar los cortes y modificaciones que en su día recibieron, muchas de las que se prohibieron siguen estando inéditas o lo han estado hasta muy recientemente... Las nuevas historias literarias no otorgan a la censura la función explicativa que merece. En definitiva, seguimos sin saber de forma cabal cuál fue la verdadera influencia de los censores sobre la producción literaria y su recepción.

El entramado represivo sobre el que se asentó el régimen franquista se basó en individuos que adquirieron un inusitado poder con implicaciones sociales, políticas y económicas. Esto hizo que el sistema literario y editorial durante el franquismo se viera profundamente contaminado. Esta contaminación derivó en la adulteración de funciones, como la que se produjo entre críticos y censores, que, en distintas forma y medida, intervienen en la inserción e interpretación de una obra en el campo cultural. Destacar la figura de Antonio Iglesias Laguna es, por lo tanto, una oportunidad de conocer mejor la historia cultural española del siglo XX a partir de un ángulo inédito. Su papel de mediador en tanto crítico y censor -figuras ambas ignoradas en los estudios literarios pero de capital importancia para determinar la sucesión de movimientos literarios, de procesos de canonización y la presencia pública de los autores- puede iluminar variables de nuestra historia literaria hasta ahora obviadas. El análisis y estudio de algunos ejemplos de su obra crítica podría servir para concretar hasta qué punto la crítica literaria y la censura editorial, esto es, mediaciones legítimas e intromisiones del poder ilegítimas respectivamente, estuvieron relacionadas durante la época franquista, creando mistificaciones en el campo literario en su conjunto. Asimismo, creemos que podría llevarnos a demostrar la heteronomía del sistema literario en este periodo y cómo la política y las relaciones de los escritores con el régimen pudieron resultar determinantes para contribuir a que una obra pasase a formar parte del canon literario.

Este artículo tiene como objetivo fundamental, por tanto, analizar la intervención de Iglesias Laguna como censor, para lo que trabajaremos con los expedientes de censura en los que él intervino ${ }^{2}$, que se conservan en el Archivo General de la Administración (AGA), en Alcalá de Henares. Contrastaremos dicha labor censora con la que ejerció como crítico para el diario $A B C$ y la revista La Estafeta Literaria. La información obtenida será analizada con ayuda de fuentes

\footnotetext{
${ }^{1}$ Los efectuados por Pilar Godayol, Fernando Larraz, Ana Martínez Rus, Francisco Rojas, Eduardo Ruiz Bautista, etc.

2 Se han localizado los informes que firmó entre 1967 y 1972, pero es posible que haya informes anteriores a esta fecha.
} 
secundarias sobre la censura franquista y el sistema cultural durante el franquismo. Para ello, partimos de la hipótesis de que, si bien censurar y criticar son actos de interpretación de los textos literarios de índole diferente y en consecuencia pueden dar lugar a veredictos también distintos, los actos de lectura desde la perspectiva censoria y desde la perspectiva crítica tienen en común determinadas prácticas retóricas y argumentativas que los implican mutuamente. En consecuencia, cuando un mismo sujeto ejerce ambos, puede resultar inevitable que existan contaminaciones que limitan o incluso impiden la objetividad necesaria del crítico.

En este sentido, por su doble condición de crítico y censor con destacada dedicación a ambas labores, la figura de Iglesias Laguna resulta paradigmática. No fue el único de los censores del Régimen que actuó como crítico literario. En la misma época, Saturnino Álvarez Turienzo redactaba informes de censura y publicaba reseñas en el Boletín de Orientación Bibliográfica, aunque eran más quienes se encargaban de censurar obras de sus coetáneos mientras se dedicaban a la creación literaria ellos mismos, como sucedía en los casos de Pedro de Lorenzo, Leopoldo Panero o Ángel Vázquez, característica que también compartía, aunque de manera mucho más ocasional y secundaria, el propio Iglesias Laguna.

Después de establecer las diferencias que debería haber, idealmente, entre las figuras del crítico literario y el censor, nos acercaremos a la figura de Iglesias Laguna para comprender el contexto en que se enmarca el censor y el posicionamiento crítico y político que puede deducirse a partir de la lectura de su producción literaria y sus escritos ensayísticos e historiográficos. A continuación, se examinarán los expedientes de censura que redactó, sus reseñas y su libro Treinta años de novela española (1938-1968) (1969), a fin de comprobar si los juicios que merece un autor por su posición política o sus avatares vitales influyen a la hora de que Iglesias Laguna evalúe su obra. Para facilitar el escrutinio dividiremos el análisis en dos partes: primero estudiaremos el acercamiento de Iglesias Laguna a la narrativa del interior y luego consideraremos el trato que le da a la narrativa del exilio ${ }^{3}$. Utilizaremos ese análisis para extraer conclusiones relativas a las obras que han entrado a formar parte del canon literario y las influencias que tuvo el censor en ello.

Aparte del acercamiento a la figura de Iglesias Laguna en relación con el tratamiento que hace de los escritores exiliados en Treinta años de novela española que realizó Fernando Larraz en El monopolio de la palabra (2009), no hay antecedentes de estudios enfocados al trabajo de un críticocensor desde el campo literario -sí se ha estudiado el trabajo de los censores desde el de la Historia (Ruiz Bautista, 2005), aunque nunca se ha analizado la figura del crítico censor-. Por ello, proponemos como metodología el análisis de las reseñas que aparecen publicadas y de los juicios que establece en Treinta años de novela española (1938-1968) en busca de valoraciones no basadas en criterios objetivos, sino en la voluntad de predisponer al lector a favor o en contra de un autor por cuestiones extraliterarias. Contrastaremos esa información con los juicios que mantenía la crítica oficial y que se pueden extraer de los informes de la censura de las novelas. Así, trataremos de demostrar que los criterios no estaban lo suficientemente diferenciados y que, durante el

\footnotetext{
${ }^{3}$ Se estableció esta división teniendo en cuenta los distintos tratamientos que daba Iglesias Laguna a los escritores de cada grupo. De manera similar había organizado él la narrativa española de 1970 en La Estafeta Literaria ("La narrativa española en 1970". La Estafeta Literaria 459 (1971): 18-21): los escritores exiliados e hispanoamericanos, los novelistas jóvenes, los consagrados y las mujeres merecían ya un tratamiento diferenciado en su artículo.
} 
Franquismo, había un sector de la crítica literaria oficial que realmente no dirimía entre censura y crítica literaria.

\section{CENSURAR Y CRITICAR}

Criticar y censurar, en sus acepciones más amplias, son conceptos que pertenecen a campos semánticos afines. El censor es un mediador que lee una novela a fin de discriminar lo correcto de lo incorrecto, de la misma manera que lo hace un crítico literario, pero con un objetivo distinto. El crítico se acerca a una obra para informar al lector de lo que se va a encontrar, orientarlo y ofrecer un juicio valorativo basado en su formación, experiencia y perspicacia. El censor, partiendo de unos criterios heterónomos proporcionados por el aparato de represión del Estado para el que trabaja, aborda la lectura con el objetivo de resolver si va a permitir la comunicación entre el autor y la sociedad y, en caso afirmativo, bajo qué condiciones; es decir, si se va a autorizar que un texto tenga vida pública. En ambos casos, se procede a una criba, a una discriminación de lo aceptable. Sin embargo, mientras la criba que realiza la crítica literaria se abre al diálogo y a la formación y participación colectiva en una esfera de discusión pública sobre cuáles son los valores literarios e intelectuales y cómo se reconocen en un texto, la censura cierra esa esfera de debate.

Con la formación de la crítica literaria como saber, el especialista, el crítico literario, se convirtió en la persona que posee las destrezas para aplicar criterios que, aun inseparables de la ideología en su sentido más amplio -social, político, económico, moral, religioso...-, atendían a la particular forma retórica del discurso literario y a su significación. La figura que crean los sistemas dictatoriales del censor-crítico contamina esa independencia, lo cual no sería rechazable si no fuera porque los criterios morales, religiosos, filosóficos, políticos... no son libre y públicamente aceptados por este crítico censor, sino que emanan de un poder único al que el crítico-censor entrega su inteligencia. Con ello, resulta inevitable poner en duda la autonomía de criterio del censor cuando hace crítica aparentemente literaria. Parece difícil que un mismo individuo pueda asumir, de forma totalmente independiente, prácticas tan diversas de lectura de textos de la misma naturaleza y a menudo, de un mismo texto, discerniendo completamente entre los criterios del censor y los del crítico.

A partir de estas consideraciones, podemos plantear la hipótesis de que en un caso tan claro como el de Antonio Iglesias Laguna su desempeño en un ámbito era susceptible de verse contaminado por el otro, hasta el punto de no poder diferenciar claramente entre las pautas que debía utilizar a la hora de escribir un informe de censura y una crítica literaria en prensa. Esta mezcla de criterios para producir textos que debían tener objetivos distintos era beneficiosa para el Estado, ya que el momento de actividad crítica de Iglesias Laguna en medios prestigiosos con una amplia difusión coincide con una etapa de aperturismo político en la que se quería dar a la dictadura apariencia democrática. En consecuencia, era recurrente la corrupción de cualquier discurso en apariencia apolítico con fines propagandísticos. 


\section{ANTONIO IGLESIAS LAGUNA}

La ausencia de estudios monográficos sobre Antonio Iglesias Laguna dificulta la posibilidad de reunir datos sobre su biografía. Al acudir a los juicios que realizaron los amigos del censor en la prensa justo después de su muerte encontramos datos que se contradicen entre sí, y también con los expuestos años después en textos teóricos sobre la censura o el panorama cultural del tardofranquismo.

Entre los datos que podemos dar por ciertos están los relativos a sus fechas de nacimiento y muerte. Antonio Iglesias Laguna nació el 25 de mayo de 1927 en Madrid y murió en la misma ciudad 45 años más tarde, el 9 de noviembre de 1972. Estudió durante la Segunda República en el Liceo de los Amigos de la Unión Soviética (Orgaz, 1972: 13), y, en 1936, comenzó a recibir clases de dibujo en la Escuela de Bellas Artes de Madrid (Orgaz, 1972: 14). Acudía a la Escuela con su padre, con quien trabajaba como zapatero remendón para pagarse los estudios. Ocho años más tarde, en 1944, se licenció en Filosofía y Letras. Se hizo mecanógrafo y en 1950 se fue a Pakistán, llamado por el primer cónsul español en el país. Empezó así su trabajo como funcionario de embajada, que lo llevó a residir en varios países de Europa, África, Asia y América entre 1950 y 1961. Regresó a España desde Alemania, casado y con dos hijas. Tendría dos niños más en los siguientes años, mientras trabajaba en el Ministerio de Obras Públicas (Orgaz, 1972: 14) y hacía traducciones del alemán, frecuentemente de libros de matemáticas o de filosofía.

Pero su vocación siempre fue la de escritor. Iglesias Laguna publicó su primer poemario, Esperanza de la carne, en Toledo, en la imprenta Gómez Menor, en 1961, el mismo año que empezó a trabajar en La Estafeta Literaria, una revista cultural oficial que dependía del Ateneo de Madrid. Cinco años después, seguiría a los poemas la que calificaría como "la obra de su vida" (Orgaz 1972: 14), la novela Dios en el Retiro. Como escritor publicó otras novelas (Ser hombre y Sostenes para una guerra) y libros de poesía (además de Esperanza de la carne publicó Cancionero de ausencias y participó en la antología Esa fría poesía de estos días, dirigida por el escritor Rafael Flórez), de viajes (La India, con vacas y sin ingleses) y ensayos (¿Por qué no se traduce la literatura española?, Política y literatura), que en general recibieron nula o muy escasa atención por la crítica. Treinta años de novela española (1938-1968) fue el ensayo que le valió a Iglesias Laguna, en 1970, el Premio Nacional de la Crítica, que seguía a algunos premios de menor envergadura como poeta. Cuando falleció estaba preparando una nueva obra, Europa y la novela española actual, que nunca se publicó.

Iglesias Laguna participó muchas veces en jurados de premios literarios. En 1969 fue, por primera vez, miembro del jurado del Premio Planeta, y participó, asimismo, en los del Premio Novelas y Cuentos (Orgaz 1972: 14), en el Premio Miguel de Unamuno y Emilia Pardo Bazán (Premios Nacionales de Literatura) en 19704, en el premio Café Gijón y Garbo de novela juvenil, en el novela corta Ciudad de Barbastro de 1971 y en el Hucha de Oro de 1970, entre otros. Era muy solicitado entre los posibles miembros del jurado de premios literarios debido a su fama como crítico literario. Ya en su juventud había fundado una revista con Manuel Orgaz (Orgaz, 1972: 13), y a la vuelta de sus viajes como embajador empezó a trabajar para La Estafeta Literaria, de la que sería redactor jefe a partir de 1964, labor que alternaba con sus críticas en $A B C$, el

4 “Concesiones de los Premios Nacionales de Literatura", $A B C, 17 / 12 / 1970$, p. 53. 
conocido diario de orientación conservadora, monárquica y católica, y Radio Nacional de España ${ }^{5}$. Apareció, además, en un programa de Televisión Española en el que la actriz Lola Villaespesa recitó algunos de sus "Sonetos a Gunbild"6, y fue jefe del Servicio de Publicaciones de la Fundación Juan March, así como de la sección española de la editorial inglesa Tom Stacey y asesor de varias editoriales.

Además de crítico literario y escritor, Antonio Iglesias Laguna desempeñó una importante labor como lector especializado de la censura, sobre todo de textos narrativos a partir de 1967. Fue el lector especializado número 10 y 36, primero, y el 12 después. En algunos casos, las novelas para las que proponía veredictos de aprobación o denegación eran las mismas que reseñaba después para alguno de los medios para los que trabajaba. Iglesias Laguna siempre tuvo que alternar su trabajo como crítico (tanto dentro como fuera del Ministerio de Información y Turismo) con otros trabajos para las instituciones culturales del Estado: tradujo para la Editora Nacional obras del rumano, el francés y el alemán, además de los ya citados trabajos como censor y como redactor jefe de La Estafeta Literaria, revista que definiría Manuel L. Abellán como "vocero oficial del Ministerio de Información y Turismo"7.

Iglesias Laguna se suicidó la madrugada del 9 de noviembre de 1972 lanzándose por la ventana de un octavo piso de la calle Embajadores. Falleció, por lo tanto, dejando proyectos a medias, como la redacción de una historia literaria del exilio que venía prometiendo desde 1969.

\section{ANTONIO IGLESIAS LAGUNA Y LA NARRATIVA DEL INTERIOR}

En las críticas literarias que firmaba Iglesias Laguna durante el tardofranquismo se aprecia una diferencia en la manera de acercarse a una obra de autores consagrados, como podían ser José María Pemán o Luis Martín Santos, y la escritura de un autor desconocido en el panorama literario contemporáneo, como eran, por aquel entonces, Javier Tomeo o Santiago Lorén. Sin embargo, esa no es la única diferencia que se puede encontrar en los juicios que establece en sus reseñas e informes de censura en el caso de los autores y autoras del interior. Iglesias Laguna añade un condicionamiento más a sus juicios: el sexo biológico del escritor.

José María Pemán, Luis Martín-Santos, Jesús Fernández Santos y Camilo José Cela son algunos de los autores consagrados del interior sobre los que Iglesias Laguna escribe reseñas en La Estafeta Literaria y en $A B C$ o sobre cuyos libros redacta el informe de censura. De ninguno de ellos establece juicios negativos en las reseñas que aparecen publicadas en prensa, independientemente de la relación que hayan mantenido anteriormente con la censura o sus opiniones políticas. Cuando habla de novelistas de quienes no queda clara su posición política, simplemente valora su obra, sin decir nada negativo sobre ella pero sin deshacerse en alabanzas

\footnotetext{
${ }^{5}$ No hemos podido localizar el programa, pero algunas de las reseñas que pronunciaba aparecen publicadas en 1972 en Literatura de España día a día (1970-1971). Madrid: Editora Nacional.

6 "Programas de televisión”, ABC, 28/02/1962, p. 90.

7 Abellán, Manuel L.: "Una recepción privilegiada de la obra de Sender: la Inspección de libros", en Gil Encabo, Fermín y Juan Carlos Ara Torralba (eds.): El lugar de Sender. Actas del I Congreso sobre Ramón J. Sender (Huesca del 3 al 7 de abril de 1995), Instituto de Estudios Altoaragoneses e Instituto Fernando El Católico, Huesca y Zaragoza, 1997, pp. 431-442 (p. 434).
} 
hacia el autor, como sucede en las reseñas de las novelas de Jesús Fernández Santos Libro de las memorias de las $\operatorname{cosas}^{8}$ y Las catedrales". Mientras deja constancia al hilo de la primera de "la pureza del estilo, ese estilo tan peculiar del autor, donde nada falta y nada sobra, regido por una sobriedad espartana [...] la incisividad [sic] con que sabe recrear la atmósfera de soledad y olvido de una España mísera, patente ya desde Los Bravos; el acierto -pleno de sensibilidad - al ir calando en el alma de los personajes a través de las fluctuaciones paisajísticas" de Fernández Santos, en la segunda aprovecha el juicio positivo de la novela para desautorizar a los escritores hispanoamericanos, postura que generalizó después en Treinta años de novela española y que se correspondía con la recurrencia entre la crítica oficial de minusvalorar a los escritores hispanohablantes que no fueran españoles: "Jesús Fernández Santos ha escrito un buen libro. Sin fantasías. Las fantasías exteriorizantes - tan hispanoamericanas, tan de extroversos [sic] aún no replegados en su yo más íntimo- me parecen menos relevantes que la búsqueda de lo sobrenatural por los senderos de lo cotidiano".

Cuando el análisis es de la obra de un autor canonizado por su cercanía a la ortodoxia literaria y su cercanía al poder político, Iglesias Laguna no se limita a opinar que la obra es buena, sino que alaba al autor, se sitúa un peldaño por debajo de él y lo admira, como sucede en el caso de "don José María Pemán", a quien tilda de gran hombre, y que "los grandes hombres no se concretan a una sola actividad, aunque entre sus muchos saberes haya uno al que deban principalmente su fama"10. Ningún otro escritor merece ese trato de entusiasmo rayano en el fervor, ni se habla de él de la manera en que lo hace con Pemán, reconocido intelectual orgánico del régimen desde su primer momento, que fue descaradamente promocionado por este y cuya obra hoy en día es escasamente reconocida.

Camilo José Cela había enviado a la censura San Camilo, 1936 a principios de 1969. Como ocurría en muchas ocasiones en las que este autor, amigo de los jerarcas Manuel Fraga, Carlos Robles Piquer y muchos de los censores en nómina, quería publicar una obra, el proceso que siguió la novela no fue el mismo que el de muchos de sus coetáneos. No solo consiguió material para escribirla gracias al ministro, Fraga, que extrajo de los archivos de la Hemeroteca Municipal de Madrid los fondos documentales que necesitaba el autor para su redacción, sino que, antes de enviar el mecanoscrito a consulta voluntaria dirigió un escrito a Fraga justificando la importancia de que su novela no sufriera cortes de la censura, aportando los datos que tendrían que tener en cuenta los censores para dictar un veredicto ${ }^{11} \mathrm{y}$ proponiendo, asimismo, tres nombres que pudieran leer la novela para la censura: Juan Rof Carballo, psiquiatra y amigo personal de Cela; Luis Díez Alegría, militar, que acababa de ser nombrado director de la Guardia Civil; y Saturnino

\footnotetext{
8 Iglesias Laguna, Antonio: “Libro de las memorias de las cosas de Jesús Fernández Santos”, ABC, 27/5/1971, pp. 112 y 117.

${ }^{9}$ Iglesias Laguna, Antonio: “Las catedrales de Jesús Fernández Santos”, ABC, 16/7/1970, pp. 101 y 105.

10 Iglesias Laguna, Antonio: “El horizonte y la esperanza de José María Pemán”, ABC, 10/9/1970, pp. 89 y 91.

11 “1. No es una novela de guerra sino una novela en la guerra. 2. Su acción discurre, salvo ligeras alusiones a otros puntos geográficos, íntegramente en Madrid y los desmanes que por aquel tiempo en Madrid se cometieron quedan claramente señalados. 3. Ni aludo, por tanto, a los desmanes que hubieran podido cometerse en la zona nacional, ya que ésta queda fuera del ámbito de mi novela. 4. No he empleado un solo dato que no haya obtenido o comprobado en libros publicados en España sobre este tema. 5. Mis licencias léxicas o de situación no son más ni mayores que las de cualquier otro libro mío publicado bajo tu mandato".
} 
Álvarez Turienzo, sacerdote y deudor de Cela, que siete años antes había conseguido que participase en un ciclo de conferencias en sustitución de Pedro Laín Entralgo (Larraz, 2014: 152-155).

Después de un informe negativo que recomendaba la prohibición del libro, este pasó a Álvarez Turienzo, que efectivamente se vio obligado a defender la publicación de una novela sobre la cual se preguntaba "si a otro autor que a Cela se le tolerarían sus atrevimientos" y de la que "tapando los oídos, yo la autorizaría"12. Se envió entonces San Camilo, 1936 a Iglesias Laguna. El censor era conocido de Cela, que le había propuesto publicar su estudio sobre la traducción al alemán de La familia de Pascual Duarte en los Papeles de Son Armadans. Cela se había dirigido entonces a Iglesias Laguna, llamándolo amigo, recordándole su encuentro en la tertulia del Gambrinus.

En el informe que escribe Iglesias Laguna no muestra ninguna condescendencia hacia Cela. Se refiere en su informe a las "aberraciones eróticas" de San Camilo, 1936, critica el "propósito comercial y epatante" de la obra y propone veintiséis tachaduras. Cela había expresado en su carta a Fraga del 25 de julio su temor a las tachaduras: "Si la novela me la llega a retirar el juez no pierdo más que el dinero, pero si a la novela le dan media docena de cortes perdería lo que me importa más, bastante más que el dinero: perdería la novela misma y la mucha ilusión que en ella he puesto"13. Iglesias Laguna le obligaba a hacer lo que precisamente trataba de evitar, tener que eliminar pasajes de su obra. A pesar de los informes negativos, el veredicto final fue el de autorizarla sin supresiones.

Esta postura que adopta Iglesias Laguna al evaluar la obra de Cela para la censura no la mantiene en la reseña de San Camilo, 1936 que escribe para La Estafeta Literaria ${ }^{14}$, en la que resalta que es la "última de sus novelas en el tiempo y primera en calidad". Se deshace en alabanzas hacia la novela de Cela, que no es una novela más de la guerra civil, sino "una de las mejores".

La opinión negativa de San Camilo, 1936 que aparece reflejada en el informe de censura de Iglesias Laguna no tiene que ver únicamente con los pasajes que pudieran parecerle censurables, sino que apela directamente a la construcción de la novela, a su objetivo y su propósito. Este punto de vista, que no se muestra en ninguna parte de la reseña se debe a que Cela pertenece al grupo de escritores consagrados al que nos referíamos antes. Si bien se atreve a relativizar el valor literario de la obra de Cela en Treinta años de novela española, parece que sus reticencias a afirmar en su libro que novelas como La familia de Pascual Duarte sean importantes y estén bien escritas responden al objetivo de culpar a la censura de los primeros años del franquismo, de la que quería distanciarse el régimen ya en aquellos años, acorde con la imagen de aperturismo político que se quería inculcar: "en años de censura rígida no se atreve a llamar a las cosas por su nombre y reduce voluntariamente a peripecia sentimental lo que podría haber tenido valor paradigmático como documento vivo de la España de 1922” (Iglesias Laguna, 1970: 225).

\footnotetext{
12 AGA (03) 50 66/03466, Exp. 69/9556.

13 Fundación Camilo José Cela, cartas facilitadas por Fernando Larraz.

${ }^{14}$ Iglesias Laguna, Antonio: "La guerra y el placer”, La Estafeta Literaria, 437, febrero de 1970, pp. 257-258.
} 
El trato sistemáticamente positivo que reciben en público las novelas de autores consagrados se mantiene con ciertos autores que, si bien no eran tan conocidos, sí merecían un trato de favor por su importancia fuera del panorama literario. Iglesias Laguna examina novelas de compañeros suyos en La Estafeta Literaria, como Francisco Umbral y Jorge Cela, hermano menor de Camilo y uno de los editores de Alfaguara. Umbral es para Iglesias Laguna un ejemplo de juventud y renovación literaria, es un escritor que "escribe maravillosamente; tiene muchas cosas que decir"15. Con El Giocondo el escritor "denota ya madurez novelística"16. Esta novela había sorprendido y espantado a los censores que la revisaron debido a la ilustración que se hace de los círculos homosexuales madrileños. Fueron cuatro los lectores que la examinaron, y solo uno, Alfonso Álvarez Villar, profesor de literatura en la Universidad de Madrid, vio la novela "cien por cien autorizable" 17.

Iglesias Laguna, que también la examinó, opinaba que "no es una novela amoral, antes al contrario se muestra su vida como es: sucia, viscosa, un poco ridícula, llena de celos menudos y pasiones torvas" 18 , pero incluyó la recomendación de unas tachaduras, que fueron las que finalmente se hicieron. En la reseña que realiza después de su publicación deja constancia de la fidelidad de las representaciones homosexuales de la obra, pero elimina los adjetivos negativos. Ya no habla de que sea "ridícula", sino de que "puede gustar o no gustar, ser grato o ingrato, atrayente o repelente; pero interesa, es ameno, está muy bien escrito y revela la evolución de un novelista joven"19.

Jorge Cela Trulock, defendido siempre por su hermano, que avisaba del depósito de las obras del menor al ministro para conseguir el mismo trato de favor para Jorge que él tenía20, era también compañero de Iglesias Laguna en La Estafeta Literaria y tenía gracias a su hermano mucha más influencia de la que podría alcanzar Iglesias Laguna, que lo defendía y halagaba a través de sus reseñas. El crítico, que podía llegar a mostrarse muy incisivo y directo con otros escritores, no se revela así cuando reseña las obras de su compañero de trabajo, que "posee una retórica propia"21, y de quien admira su "gracia novelística" 22.

Hay un grupo de autores a los que examina Iglesias Laguna que eran jóvenes, escribían novelas cuyos temas o subgéneros los eximían de los problemas de la censura, o bien eran conocidos por escribir novelas que no suponían ninguna incomodidad para la administración: es el caso de las obras que censura Iglesias Laguna de autores como Francisco García Pavón, Javier Tomeo, Santiago Lorén o Vicente Soto. Es quizás el único caso en que podamos afirmar que las críticas de Iglesias Laguna no están basadas en juicios políticos o en amiguismo e intereses espurios.

\footnotetext{
15 Iglesias Laguna, Antonio: “El Giocondo de Francisco Umbral”, ABC, 3/12/1970, p. 117.

16 Ídem.

17 AGA 66/03712, Exp. 69/12843.

18 Ídem.

19 Iglesias Laguna, Antonio: “El Giocondo de Francisco Umbral”,ob. cit., p. 123.

20 Fundación Camilo José Cela, cartas facilitadas por Fernando Larraz.

${ }^{21}$ Iglesias Laguna, Antonio: “¿Un callejón sin salida?”, La Estafeta Literaria, 449, agosto de 1970, p. 345.

22 Ídem.
} 
Encuentra en García Pavón, creador de un personaje, Plinio, detective manchego que "dista mucho de poder compararse con sus grandes colegas, desde Hércules Poirot a los superagentes de John Le Carré", un "humorista fuera de serie"23, aunque a veces, incorporando a la reseña crítica los criterios del censor, lamente que "en lo erótico se le fuera la mano al escritor" 24 . De Javier Tomeo, que estaba entonces iniciando su fecunda trayectoria como autor de literatura fantástica, opina en el informe de censura de Ceguera al azul (1969) que es un autor desconocido y con talento. Santiago Lorén, por el contrario, escribe con Los gerontes una "novela francamente mala y pretenciosa" 25 , dejando ahora asomar al crítico literario en un informe de censura, pero no se adivina en ningún momento de su crítica que los juicios se deban a otra cosa más que a la opinión del censor de que la novela carece de interés literario.

Algunos de los textos que evalúa Iglesias Laguna fueron redactados por conocidos republicanos que ya habían tenido problemas anteriormente y los tendrían más tarde con la censura. Es el caso de Carlos Rojas, cuyas primeras obras eran alegorías filosófico-fantásticas de base política (Larraz, 2014: 270) que saltaron las alarmas de los censores y fueron mutiladas antes de poder publicarse: De barro y esperanza (1957) y El futuro ba comenzado (1958). Peor suerte tuvo La serpiente y el arco iris, que fue presentada a la censura en 1960 y no pudo publicarse hasta 1962, con un cambio de título y notables diferencias textuales ${ }^{26}$, que "descargaban de contenido ideológico la novela" 27 .

Seis años después, Rojas ganaría el Premio Nacional de Literatura Miguel de Cervantes por Auto de fe, de la que se quiso hacer una película cuyo guion tuvo que ser defendido por Robles Piquer para pasar la censura, que lo había prohibido en primera instancia. Iglesias Laguna se encarga del veredicto de Aquelarre (1970), una novela de corte histórico que no supuso ningún problema. Ya en el informe menciona Iglesias Laguna que "fatiga, cansa, y a ratos aburre, por la demasía lingüística"28; idea en la que abunda en la reseña que escribe para La Estafeta Literaria, en la cual, además de marcar que los recursos que utiliza "hacen fatigosa la lectura", hace hincapié en la "catarata verbal que anega y ahoga". Y finaliza su análisis con un avance de los peligros de la escritura de Carlos Rojas que vaticinan el declive de la obra del autor y hacen que el lector dude del valor de cualquier comentario positivo que haya podido hacer con anterioridad:

Aquelarre marca un momento crucial en la evolución de Carlos Rojas. Peligro que acecha al escritor: despojar su obra de toda encarnadura vivencial y convertirla en carnaza, en carroña, en despojo, en detritus. La baba tóxica de los personajes debe estar atemperada por el calor humano. De lo contrario se vuelve mucilaginosa, animal. El baboso se convierte en babosa. ${ }^{29}$

\footnotetext{
23 Iglesias Laguna, Antonio: "Un Plinio más humano”, La Estafeta Literaria, 444-445, mayo de 1970, p. 313.

${ }^{24}$ Iglesias Laguna, Antonio: “Una semana de lluvia de Francisco García Pavón”, ABC, 17/6/1971, p. 121.

25 AGA 66/05934, Exp. 70/8171.

26 Domínguez Cid, Nuria: "Carlos Rojas, entre La serpiente y el arco iris y Las llaves del infierno", Represura, 3, 2018, pp. 102-149.

27 Ídem

28 AGA (03) 50 66/06121, Exp. 70/10015.

${ }^{29}$ Iglesias Laguna, Antonio: “Aquelarre de Carlos Rojas”, ABC, 25/2/1971, p. 97.
} 
Distinto al de los hombres es el caso de las mujeres cuyas obras analiza Iglesias Laguna. Raquel Conde Peñalosa, en La novela femenina de posguerra (1940-1960), expone que el crítico realiza, con Treinta años de novela española (1938-1968), uno de "los trabajos más serios y más elaborados sobre literatura de posguerra" (Conde, 2004: 87), en el que se establecen "juicios hechos con un rigor crítico no sexista, manejando un discurso coherente sin modulaciones diferentes (de blanda condescendencia o antifeministas) para las obras femeninas" 30 . Conde Peñalosa matiza en relación con críticos como Ignacio Soldevila, Gonzalo Sobejano y el propio Iglesias Laguna que "sus consideraciones no se desprenden totalmente de los prejuicios sobre la mujer existentes en el momento, y por ello se van a mover a medio camino entre la comprensión de la diferencia y una imagen tradicional de la mujer, como ser sensible y asistencial"31.

Sin embargo, los juicios que reciben las escritoras a las que critica Iglesias Laguna en sus reseñas distan mucho de los de los hombres, ni siquiera si se consideran como atenuantes los prejuicios sobre el sexo femenino existentes en el momento. La postura que adopta el crítico es la propia de la censura en su trato hacia las mujeres. En Discurso de autora: género y censura en la narrativa española de posguerra, Lucía Montejo escribe un resumen muy acertado de la manera que tenía la censura de tratar a las escritoras durante el franquismo:

Cuando el discurso de la autora se aleja de la novela rosa y se acerca al realismo, a la expresión de experiencias personales de carácter fictivo pero vinculadas a su realidad social y cultural, los censores no solo les aplican las mismas restricciones que a los varones, sino que en los informes se refleja un mayor castigo cuando juzgan las opiniones morales que ellas vierten, cuando describen con la crudeza necesaria una situación, cuando se refieren a la situación confinada y silenciada de la mujer, cuando utilizan un lenguaje ajustado, que pronto tachan de poco conveniente (Montejo, 2010: 89)

Disponemos de dos expedientes informados por Iglesias Laguna acerca de sendas novelas escritas por mujeres, que nos permiten contrastar los juicios de Montejo. Son las novelas Entre dos oscuridades, de Carmen Kurtz y Julia, de Ana María Moix. Moix, según leemos en el informe de censura de Iglesias Laguna, quiere publicar una "novela intrascendente y mal escrita, con abundantes incorrecciones gramaticales y falta de profundidad, pero con un cierto encanto", mientras que en el caso de Carmen Kurtz se trata de un "libro bien escrito, con leves deslices gramaticales y con emoción sostenida". Si bien parece que la obra de Kurtz, que ya había escrito nueve novelas y bastantes cuentos, había cosechado cierto éxito editorial y había sido tanto finalista como ganadora de varios premios literarios 32 no es tan mala, a su juicio, como la de Ana María Moix, que se estrenaba con Julia, ninguna de ellas merece un juicio enteramente positivo. Y esto se debe a que ninguna de las escritoras puede merecer el apelativo de "escritora consagrada", por mucho que hayan publicado, por muchos galardones que hayan recibido o por muy interesantes y bien escritas que estén sus novelas, sino que están en constante aprendizaje, en progreso, sin llegar nunca a graduarse, a diferencia de los hombres.

\footnotetext{
30 Ídem.

31 Ídem.

32 El Premio Ciudad de Barcelona 1954 por Duermen bajo las aguas, el Premio Planeta 1956 por El desconocido, fue finalista del Premio Café Gijón 1963 con En la oscuridad y ganó el Premio Lazarillo 1964 por Color de fuego.
} 
Que aparecieran estos juicios en los informes de censura, como hemos comentado, es hasta cierto punto comprensible, pero no lo es tanto que se utilicen los mismos parámetros para evaluarlas desde una reseña literaria. Sin embargo, como indica Lucía Montejo,

la invisibilidad y la exclusión son los parámetros en los que estas escritoras se mueven y cuando la crítica habla de ellas, lo hace desde la conciencia de superioridad genérica, desde el convencimiento que continúa en el inconsciente colectivo de que la única literatura legítima es la escrita por hombres, y su actividad creadora se juzga siempre con suspicacia, reserva, ironía, asombro, todo lo más, benevolencia, tolerancia protectora (Montejo, 2010: 86)

Esta discriminación en la crítica por razones de género se ve muy claramente en su discurso crítico. Cuando Iglesias Laguna habla de las influencias de Ladridos a la luna, de Marta Portal, menciona a Ricarda Huch en Ludolf Urseu y a Carmen Laforet en Nada. Concha Alós es comparada con Emilia Pardo Bazán, y no con ningún otro escritor realista. Y no solo muestra las diferencias entre mujeres y hombres en sus posibles influencias, sino que, cuando se pregunta si Ladridos a la luna está lograda como novela de amor afirma que "resulta difícil opinar, puesto que la mentalidad femenina difiere diametralmente de la masculina en esta materia. Digamos tan solo que, desde un punto de vista femenino, no cabe analizar con mayor lucidez las reacciones de una hembra voluntariosa y enamorada que intuye la pérdida próxima del amante"33. Se insinúa también que las mujeres no son capaces de analizar de manera objetiva y racional los problemas, punto de vista, sin duda, reservado exclusivamente a los hombres:

Mi análisis ofrece el inconveniente de ser masculino. Desde un ángulo femenino, las incoherencias no son tales, y la heroína se comporta con lógica. Con lógica femenil. La filosofía de la hembra enamorada -que, al evocar a Marcos, rememora también otros amores- no puede ser más vital, más biológica, por no decir animal: "Un congénere es alguien de quien se huye, alguien a quien se ataca, o alguien con quien se yace. Se va, y la memoria animal no sigue teniéndole presente. Regresa, y iqué simple!, hasta el olfato le previene de las intenciones del recién llegado. Y todo es uno: olisquear y erizarse para el ataque, o huir, o aprontarse para el coito" (pág. 51). Adivino en esta actitud un gran miedo a la soledad (quizá sea el miedo a la soledad lo que induce a las mujeres a soportarnos). ${ }^{34}$

Es incomprensible para Iglesias Laguna pensar que una mujer pueda, como sí sucede con los hombres, realizarse como persona sin convivir con un varón. A ello se suma lo discutible que resulta llevar a cabo un análisis psicológico de la autora en una reseña, incurriendo en el error de identificar narradora y autora. Estos discursos, difundidos en medios de tanto alcance, fomentaron la exclusión de los libros escritos por mujeres de los cánones, limitaron la recepción de la novela a un público exclusivamente femenino, y contribuyeron a la legitimización del discurso franquista, que pretendía recluir a la mujer al ámbito doméstico y limitar su actuación en la esfera pública, en vez de limitarse a realizar una crítica literaria.

El tono paternalista que adopta Iglesias Laguna con algunos de los escritores jóvenes no desaparece al realizar juicios sobre escritoras. En algunos casos, como el de Luisa Llagostera, autora bastante desconocida cuando Iglesias Laguna escribió la reseña de Como la tierra, en 1970,

\footnotetext{
33 Iglesias Laguna, Antonio: "Lectura recomendable", La Estafeta Literaria, 459, enero de 1971, p. 417.

34 Ídem, p. 418.
} 
se entiende que diga que "los fallos obedecen a la falta de madurez" 35 o señale como defecto "la carencia de estilo o, si se quiere, el estilo pobretón, sincopado, con infinitos puntos y aparte" 36 . Es irónico que finalice la reseña, después de haber hecho un recorrido por todas las faltas gramaticales, cacofonías, abusos de tiempos verbales y falta de vocabulario de la autora, cometiendo él mismo un fallo, al afirmar que está seguro de que "Luisa Llagostera, con mucho camino por delante, cuidará más el idioma en novelas futuras. Novelas que debe de escribir [sic], puesto que vocación y talento no le faltan". Este mismo tono paternalista hasta cierto punto es justificable también en la evaluación de Ladridos a la luna, de Marta Portal, que sumaba con ella cuatro novelas, por lo que se atreve a juzgar que "aún le falta oficio a Marta Portal, pero veo en ella una escritora que dará mucho que hablar y que deja poco que desear" 37 .

Sin embargo, este tipo de juicios se mantienen tanto en las obras de Carmen Kurtz como en las de Concha Alós, dos novelistas que, quizás no casualmente, aunque no han llegado a formar parte del canon, no eran en absoluto nombres desconocidos en la época, y cuyas obras tienen interés tanto literaria como socialmente. Concha Alós publicaba su sexta novela en 1969, había ganado dos veces el Premio Planeta (en 1964 con Las hogueras y, antes, en 1962, con Los enanos, aunque tuvo un problema de derechos con la editorial Plaza \& Janés y se lo retiraron) y tenía un éxito de ventas considerable. La madama, que Iglesias Laguna reseñó para $A B C$ en 1970 , fue aprobada en censura, pero se imponían tachaduras, algunas de considerable longitud, en 42 páginas ${ }^{38}$. Aunque se cambiaron algunos de los pasajes que se tenían que tachar en vez de eliminarse, la novela perdió gran parte de la crudeza en las descripciones. Aun así, para Iglesias Laguna la poda realizada no parecía haber sido suficiente para dotarla de mérito literario:

Escrita en un lenguaje innecesariamente crudo. Digo innecesariamente -y me abstengo de añadir citas-, porque la crudeza no le va a una mujer culta y refinada como Concha Alós. No importa que los vocablos soeces sean puestos en boca de personajes vulgares en los momentos oportunos. Sin duda, esos personajes hablan así; pero la novela no es una cinta magnetofónica del lenguaje del arroyo, sino un filtro del lenguaje, una elección continua entre los distintos elementos, las diversas posibilidades de la realidad. La autora lo sabe y procura que sus héroes se expresen correctamente, sin caer en lo coloquialmente amorfo; pero en ocasiones no puede huir la tentación de ser "realista", de bucear en diccionarios secretos, de usar tacos para que no se diga. Para que no se diga, ¿qué? Probablemente, que no es una "varona", entendida la palabra en el sentido literario aplicado a la Pardo Bazán. Esto, en el fondo, me parece un complejo, un complejo corriente entre muchas escritoras: el temor a ser tomadas por femeninas, contra el cual reaccionan engolando la voz y empleando voces y locuciones que, en sus labios, suenan a falsas. ¿Por qué no ha de ser femenina la mujer, por qué ha de imitar en todo al hombre?39

La escritura de Concha Alós se asemeja a la de Emilia Pardo Bazán en la medida en que las dos narradoras escriben novelas de corte realista cercano al naturalismo. Iglesias Laguna utiliza el símil para rebajar el valor de Alós como escritora, ya que señala un supuesto desajuste entre su

\footnotetext{
35 Iglesias Laguna, Antonio: “Como la tierra de Luisa Llagostera”, ABC, 31/12/1970, p. 95.

36 Ídem.

${ }^{37}$ Iglesias Laguna, Antonio: "Lectura recomendable", La Estafeta Literaria, ob. cit. p. 418.

38 Sería interesante analizar el tipo de tachaduras que se le imponen a la autora, dado que en la mayor parte de las ocasiones no son por razones morales o políticas, sino por utilizar un vocabulario "que no era adecuado", como la expresión "gallego de mierda" (p. 105 del mecanoscrito de AGA (03) 50 66/03415, Exp. 69/8952).

39 Iglesias Laguna, Antonio: “La madama de Concha Alós”, ABC, 4/6/1970, p. 116.
} 
género y su escritura: hace a la mujer menos mujer por el hecho de no escribir novelas de corte idealista como le correspondería. Iglesias Laguna, pese a todo, intenta salvar parcialmente la novela y tratar de interpretarla en clave idealista: afirma que Concha Alós procura que sus héroes no se expresen incorrectamente, pero en realidad, en la novela que Alós redactó (y no en la versión que salió publicada), los personajes se expresaban de manera más natural y adecuada a sus circunstancias vitales. La escritora, para Iglesias Laguna, por ser mujer no puede ser realista, no puede poner en boca de sus personajes y narradores exabruptos ni expresiones groseras, porque "no le va" el uso del lenguaje crudo. La mujer merece una consideración especial por serlo, y si adecúa el lenguaje al personaje que está interviniendo en cada momento corre el peligro de que se considere que está imitando al hombre. En eso acierta Concha Suárez del Otero, de quien Iglesias Laguna afirma, en una reseña sobre Me llamo Clara que "no existen complejos morbosos, escenas obscenas ni palabras malsonantes», que "rehúye los tacos y hace bien"40.

Concha Alós en La madama es mucho "menos femenina” de lo que piensa Iglesias Laguna. En la versión mecanoscrita que llegó a las oficinas del Ministerio de Información y Turismo había un pasaje de dos páginas que fue mutilado a su paso por la censura, con una descripción muy detallada y cruda sobre los problemas para defecar de los prisioneros en las cárceles de la posguerra:

Los excrementos eran generalmente muy gruesos pero formados por multitud de bolitas, como las cagarrutas de los conejos pero un poco más grandes. La mayor parte de los prisioneros iban a defecar por parejas: el paciente y el "ayudante". Este último iba provisto de una llave de abrir latas de sardinas y con ella, cuando el paciente se colocaba en adecuada posición, forcejeaba para romper el enlace de las bolitas que, de esta manera, caían poco a poco. Cuando terminaba la intervención casi siempre era necesario acompañar al sujeto en brazos: estaba casi desmayado.

De esta época de Albatera creo que nunca podré olvidar a aquel muchacho de Valls de cara saludable y cabello rubio. Todos los días se ponía en posición de defecar y estaba así horas enteras. Al rato de estar encogido empezaba a asomar el excremento, que tenía el diámetro tan ancho como las tazas de café que hay en las casas. Salía solo medio centímetro y al no poder desprenderse se descolgaba el intestino, medio palmo de tripa sangrante. Las moscas se lanzaban voraces y cubrían de una espesa capa movediza aquella especie de pene de caballo. El muchacho de Valls, cuando se desanimaba, recogía el intestino y se retiraba penosamente, con las piernas abiertas, dejando un charco de sangre en el suelo, un charco cercado de moscas. ${ }^{41}$

Resulta inverosímil que esta tachadura se deba a cualquiera de los motivos (morales, religiosos, políticos) que determinan los criterios del censor.

No obstante, más adelante Iglesias Laguna se contradice, afirmando que Concha Alós es muy femenina, ya que "en La madama abundan las escenas plenas de sensibilidad, de ternura, de mansa resignación, en compensación justa con lo acre, inmisericorde y sarcástico”. Asimismo, destaca, en una novela marcada por la pobreza, el instinto de supervivencia, el realismo de las descripciones y la crudeza, "la ternura, el estudio psicológico, la sátira”; los “detalles entrañables

\footnotetext{
40 Iglesias Laguna, Antonio: “Amor con sueco”, La Estafeta Literaria, 421, mayo de 1969, p. 159.

41 AGA 03 (50) 66/03415, Exp. 69/8952.
} 
por profundamente humanos" 42 , que consiguen acreditar "la habilidad novelesca de la autora"43. El crítico hace que la novelista encaje en el prototipo de mujer del Franquismo,

representada por las facultades afectivas, por el sentimiento y la sensibilidad, y por un conjunto de rasgos psicológicos, temperamentales, como la paciencia, la abnegación, la caridad, la generosidad, la piedad, la pureza, el espíritu de sacrificio; rasgos que la construyen sobre los paradigmas de la subordinación y la pasividad, de la frivolidad y la inconsistencia (Montejo, 2010: 82)

$\mathrm{Y}$ se muestra entonces benevolente y paternalista con una escritora que "tiene mucho que decir, y lo dice generalmente bien, a pesar del estilo gris, mate y, a veces, incorrecto". ${ }^{44}$

Dado que no le agrada la crítica social que la novelista vierte en las páginas de La madama, parte de su crítica consiste en demostrar lo errada que está, porque "está claro que Concha Alós solo ve un lado del problema: aquel que le interesa poner de relieve. Lo cual es novelísticamente lícito... pero nada más"; "La madama, allí donde es obra exclusivamente literaria, convence y conmueve. Convence y conmueve pese a los latiguillos retóricos y los clisés [sic] ¡Qué novelista será Concha Alós cuando comprenda que el escritor debe estar por encima de ciertas cosas!’’45. De nuevo hace hincapié en la imagen de que una escritora está en constante aprendizaje, mientras sus coetáneos masculinos "son" escritores. Y también de nuevo vemos a un crítico guiando su valoración por posicionamientos políticos, morales y religiosos más propios de un censor.

Otro de los elementos que aparece sistemáticamente en las críticas a mujeres es la evaluación de los aciertos y errores en el lenguaje, que no aparece en casi ninguna de las reseñas que escribe sobre novelas redactadas por varones. Aparte de los ya comentados, cuando escribe sobre Luisa Llagostera, en Ladridos a la luna, de Marta Portal, marca que "errores del lenguaje se advierten únicamente en las páginas 45, 83 y 123”46 y Carmen Kurtz, en En la punta de los dedos, también comete errores gramaticales: "Carmen Kurtz, tan menguada de vocabulario, dice "echar hojas" por "hojecer", "dar por las narices" en lugar de "dar en las narices", etc. Su sentido funcional de la prosa - nada reprobable- no excluye el refugio en una facilidad ocultadora de una pobreza expresiva" 47 .

Desde su posición de poder se dirige a todas las autoras para minusvalorar su escritura, predisponer a los posibles lectores masculinos de las obras en contra de sus novelas coadyuvando así a que su escritura quede relegada al olvido.

\section{ANTONIO IGLESIAS LAGUNA Y LA NARRATIVA DEL EXILIO}

Iglesias Laguna, como ocurría también con otros censores, demostraba hacia los exiliados prejuicios que contaminaban el examen de la obra escrutada y que no se ocultaban en la redacción de los informes, en los que, implícita o explícitamente, se alude a la condición de exiliado del autor y a su militancia política, a menudo errónea o desfasada, y también en algunas

\footnotetext{
42 Iglesias Laguna, Antonio: “La madama de Concha Alós”, ABC, 4/6/1970, p. 116.

43 Ídem.

44 Iglesias Laguna, Antonio: "Lectura recomendable”, ob. cit., p. 418.

45 Iglesias Laguna, Antonio: “La madama de Concha Alós”, ob. cit., p. 116.

46 Ídem.

${ }^{47}$ Iglesias Laguna, Antonio: “Las buenas almas provincianas”, La Estafeta Literaria, 397, junio de 1968, p. 37.
} 
reseñas de crítica literaria. Luego, como crítico, esos prejuicios subyacen de una manera más o menos disimulada a la valoración literaria de la obra y, en muchos casos, la explican. Esto ocurre en varios libros de autores exiliados de los que es primero censor y después reseñador. Por ejemplo, en la reseña que aparece publicada en La Estafeta Literaria sobre Gorra de plato (1969), de Xavier Benguerel. Al terminar la valoración, Iglesias Laguna menciona que "un cierto tufillo anticlerical, una ligera predisposición escatológica, sería lo único negativo de la novela"48. Su lectura rebasa la labor del crítico literario, se aleja del criterio objetivo que se presupone en estas prácticas. Pese a ser una reseña crítica, Iglesias Laguna no está criticando: está censurando.

En muchas ocasiones nos encontramos con que de la misma obra se comenta lo mismo en el informe de lectura y en la reseña, aunque utilice distinta retórica. Ocurre esto, por ejemplo, con La esfera (1969), de Ramón J. Sender. La única diferencia entre ambos textos (más allá de aspectos meramente formales) es que en el texto que va a salir publicado el censor se ve en la obligación de escribir una breve nota biográfica antes de proceder al análisis de la obra, en la que trata de desacreditar el valor del escritor exiliado, muy a menudo dictaminando sobre su anacronismo, y, así, ofrecer interpretaciones extraliterarias que pretenden introducir prejuicios en el lector:

Sea como fuere, hemos creado un mito Sender, y a Sender se le ensalza y se le critica sin gran conocimiento de causa. (Hasta se le denomina Sénder y se confunde su lugar de nacimiento). Sender es, para unos, un rezagado de un naturalismo entre barojiano y realsocialista que tuvo su auge en los años treinta, mas que perdiese vigencia ha mucho; para otros, Sender ha inventado el realismo mágico mucho antes que los actuales divos de Hispanoamérica y, por ende, hay que sacarle de los moldes del realismo tradicional y encuadrarle en un apartado de escritores esotéricos, fantásticos, donde asimismo tienen cabida Samuel Ros, Âlvaro Cunqueiro y Juan Perucho.49

En estas líneas el crítico no está haciendo una valoración razonada de la obra del autor, sino que sutilmente se está apoyando en determinados elementos del discurso oficial del régimen para situarla en el campo literario. Utiliza su autoridad como crítico en la institución literaria para legitimar el discurso del franquismo con respecto a la crítica hegemónica en relación con los escritores del exilio. Así, recurre, una vez más, al tópico de la mitificación de los exiliados por intereses espurios y a su desnacionalización a causa de su excesiva impregnación de tradiciones literarias extranjeras que mantenía la crítica oficial. Se entretiene en explicar que la lengua literaria del autor está desfasada como consecuencia del exilio, que, se da por supuesto, es una rémora y no una posibilidad de apertura. Además, cabe destacar la relación de autores con los que se compara a Sender: Samuel Ros, Álvaro Cunqueiro y Juan Perucho, que poco tienen que ver con él. No se compara al aragonés, por el uso de elementos maravillosos, con autores americanos tan prestigiosos en aquel momento como Alejo Carpentier o García Márquez, ni con ningún otro autor exiliado. El reseñista basa el comentario de la obra de Sender en el juicio de la crítica oficial, y utiliza sus críticas para hacer una censura indirecta de los escritores hispanoamericanos y exiliados, acorde con lo dicho en Treinta años de novela española, en cuyas páginas se afirma que las obras españolas no se traducen por "la pujanza creciente de la narrativa hispanoamericana. Hoy en día, Ernesto Sabato, Julio Cortázar, Jorge Luis Borges, Miguel Ángel Asturias, Carlos Fuentes,

\footnotetext{
48 Iglesias Laguna, Antonio: "Mi voluntad se ha muerto", La Estafeta Literaria, 415, marzo de 1969, p. 113.

49 Iglesias Laguna, Antonio: “Dos novelas y media”, La Estafeta Literaria, 431, noviembre de 1969, p. 209.
} 
José Donoso, Alejo Carpentier, G. Cabrera Infante, José Lezama Lima, Mario Vargas Llosa, Carlos Droguett, Juan Carlos Onetti y demás divos de Hispanoamérica son más populares en Europa que sus colegas españoles, a veces sin razón" (Iglesias Laguna, 1970: 13), juicio que le parece tan claro y válido que no ofrecerá más argumentación para sostenerlo.

Lo que Iglesias Laguna no explica en su reseña es que el editor Saturnino Calleja había intentado importar La esfera en 1950, cuando se había decidido que "esta novela de un emigrado español, no podrá ser autorizada, a nuestro juicio, por encontrarse en ella párrafos de tendencia dudosa, como los señalados en la página 57 , relativos a la guerra civil" ${ }^{50}$. En consecuencia, se habían intervenido todos los ejemplares que habían llegado a España y se había prohibido su importación y su venta. Tardaría dieciocho años más en ver la luz en el interior, y con no pocas tachaduras, lo cual puede explicar algunos anacronismos y fallos estructurales de la versión publicada ${ }^{51}$. El argumento de la obra, definido como "sencillo" por el primer lector de la censura en 1968, tenía un cariz simbólico-futurista, "una rara atmósfera de parábola religiosa, visión futurista, sentido profético al modo judáico [sic], bondad de religión natural, incidencia filosófica"52. Para Iglesias Laguna, Sender quería decir que "la religión constituye una necesidad vital, aunque esté adulterada. Pero las religiones son creaciones humanas y el hombre es un lobo para el hombre. La curiosa teología de Sender está expuesta -diluída [sic] - en todo el libro”. Ambos censores señalaron numerosos párrafos suprimibles ${ }^{53}$, sin los que llegaría a España, y de los que los lectores del interior no sabían nada.

En ninguna de las reseñas que aparecen publicadas de Iglesias Laguna se encarga de hacer una breve biografía del escritor más que cuando se trata de una obra publicada por un autor exiliado, no tanto para que los lectores conozcan al novelista (de ser así lo haría también con los narradores noveles), sino para justificar el desconocimiento de su obra por motivos supuestamente naturales. Así, al reseñar Vísperas (1969), la novela de Manuel Andújar, para $A B C$, repite el discurso que mantiene en la presentación de la obra de Sender:

El descubrimiento de un novelista nuestro del exilio da pie para ocuparse de su importancia narrativa, sea la que sea. Descubrimiento y no redescubrimiento, ya que Manuel Andújar carecía de significación antes de la guerra civil. Le sucede como a su amigo José Ramón Arana, el autor de esa novela impresionante titulada El cura de Almuniaced. Ciertos críticos se han dolido con sospechosa frecuencia de la ignorancia en

\footnotetext{
${ }^{50}$ El pasaje decía así: "Preguntó a Saila si sabía jugar al ajedrez y al decir Saila que sí se le iluminó el rostro. Tell miraba a Saila y al viejo como si estuviera ante dos idiotas. Mr. What comenzó a hablar de la guerra de España. Él era amigo de algunas de las personas complicadas en los trámites diplomáticos que habían dado el triunfo a los fascistas, ese triunfo era cosa decidida desde hacía más de dos años”. AGA (03) 50 21/09319, Exp. 5872/50.

${ }^{51} \mathrm{El}$ segundo informe de censura, del que se aplicaron las tachaduras, reza que "Puede autorizarse, aunque debieran suprimirse las llamadas a la violencia (12), justificación del suicidio (15), calificación de fascistas al vencedor de la Guerra España 1939 (25, 27, 28, 29, 33), masones (114), ideas religiosas (121, 129, 154, 134, 135, 144, 149, 156) y sexuales (138)" [sic]. AGA (03) 50 21/19313, Exp. 68/8781.

52 AGA (03) 50 21/19313, Exp. 68/8781.

53 En las páginas 25, 27, 28, 29 y 33 se aplicaba el calificativo de "fascista" a los "nacionales"; se hacían referencias a los masones en la página 114 ("a los curas les irrita ver el espíritu religioso (la piedad y la solidaridad humana de los fracmasones, por ejemplo) fuera de la iglesia”); alusiones a temas religiosos y sexuales en las páginas 121, 129, 134, 135, 144, 149, 154 y 146 de las galeradas. En la página 194, la afirmación de que "los milagros los hace la humildad y él [el papa] es demasiado ostentoso y suntuario".
} 
España de los libros de algunos novelistas del destierro, atribuyéndola a motivos inconfesables. No hay tales carneros. Andújar, Arana, Lamana, Airó, Barea, etc., eran seres anónimos en la España de 1936, hicieron su obra en la expatriación y, lógicamente, solo cuando ellos mismos (salvo Barea) se han resuelto a volver a la Patria, o a visitarla y publicar sus libros aquí, solo entonces ha habido oportunidad de conocerlos y valorarlos. Acusarnos a los españoles de hoy de haber sabido tardíamente de tales escritores equivale a acusar a los españoles del siglo XVII de no haber valorado las "Empresas" de Saavedra Fajardo, hasta ocho años antes de su muerte. Saavedra Fajardo se pasó la vida fuera de España y, claro está, nadie supo de él fuera del mundo cortesano hasta que optó por el regreso. 54

Se habla de descubrimiento de Manuel Andújar como si el desconocimiento precedente se debiera a la lejanía del autor de España, y no a los mecanismos de la censura, que habían imposibilitado el acceso a las novelas de los escritores exiliados de una manera especialmente virulenta y, en consecuencia, habían agudizado la incomunicación entre la literatura española del interior y del destierro. En mayo de 1949 el editor Alfonso Martín Escudero había intentado importar la primera parte de la trilogía, Llanura, de Manuel Andújar, que revisó el censor Luis Miralles de Imperial y Gómez. El censor consideró "rechazable por entero esta obra" debido a "su carácter tendencioso en cuanto al principio de autoridad, o bien por las suposiciones que se permita exponer de cohecho de un Benemérito Instituto armado de España, así como por su tendenciosidad amoral e irreverente, presentando el campo Español como algo salvaje y atrasado, con sus rancias costumbres" 55 . Ello demuestra que Iglesias Laguna falsea una realidad de la que, como censor, debía de ser bien consciente.

Del fragmento que hemos reproducido, llama la atención la nómina de escritores exiliados que aporta Iglesias Laguna. Entre ellos está, por ejemplo, Manuel Lamana, huido de la justicia española cuando cumplía pena de trabajos forzados en Cuelgamuros y autor de una novela especialmente vigilada por la censura, Otros hombres; o Arturo Barea, fuertemente vilipendiado por la crítica oficial a causa de su trilogía La forja de un rebelde, y tildado de "resentido" (Ynduráin, 1953: 73-79) y a veces confundido incluso con el dirigente de la NKVD Laurenti Beria por la similitud de sus apellidos. En contra de lo que dice Iglesias Laguna, ninguno de los dos había podido regresar legalmente a España, como tampoco otros exiliados, y sus obras se desconocieron por la vigilancia de la censura.

En este texto, Iglesias Laguna compara el estado del sistema literario en el siglo Xx con el del siglo XVII, como si la comunicación literaria y el mercado editorial fueran similares y las situaciones análogas. Sin embargo, en el contexto contemporáneo, la incomunicación se ha debido única y exclusivamente al trabajo de la censura. Menciona en esta reseña, además, El cura de Almuniaced, haciendo una valoración de la obra que acababa de ser prohibida en España, y que no sería publicada en el interior hasta 1979, ocultando la responsabilidad del Ministerio de Información y Turismo en el hecho de que la obra no se pudiera adquirir en España. Con novelas como esta, una de las mejores de la literatura española del siglo Xx, y con muchas otras, ocurría la perversión de que solo los censores podían tener un acceso normal a ellas, por lo que cualquier lectura que de ellas se diera era, para los lectores comunes, imposible contrastarla a menos que se

\footnotetext{
54 Iglesias Laguna, Antonio: “Visperas, de Manuel Andújar”, $A B C$, 15/10/1970, p. 119.

55 AGA (03) 50 66/03548, Exp. 69/10678.
} 
hicieran con ellas clandestinamente. El discurso que defiende Iglesias Laguna en estas líneas apoya la falacia difundida por los publicistas del Estado: los escritores exiliados podían regresar a España en el momento en que ellos quisieran y sus obras podían entrar en el mercado editorial pero no lo hacían, como escribe en Treinta años de novela española, debido a que "en los años de emigración crearon hogares en tierras lejanas" (Iglesias Laguna, 1970: 29).

Los juicios sobre los autores exiliados que pueden encontrarse en sus críticas no acaban ahí. Cuando Max Aub consigue publicar El zopilote y otros cuentos mexicanos (1966) ${ }^{56}$ en España, con los cortes y alteraciones impuestos por la censura, Iglesias Laguna publica en La Estafeta Literaria el primer texto de esta revista en el que aparece mencionado Aub, a pesar de ser ya entonces un autor de reconocido éxito fuera de España. Lo abre con unas consideraciones, antes de hablar de la vida de Aub, sobre lo que llama "la generación perdida", formada por los novelistas que "se ausentaron de España" (dando a entender que la expatriación no había sido forzada sino voluntaria) "para no retornar o para volver y mantenerse al pairo de los acontecimientos, incapacitándose así para influir en los novelistas jóvenes" 57 . Nada dice allí Iglesias Laguna sobre el hecho de que la primera obra de Aub publicada en España no fuera ninguno de sus Campos (que calificará después en Treinta años de novela española como una "historiografía inconexa de la guerra") ni ninguna de las novelas realistas del Madrid de la preguerra, La calle Valverde 58 o Las buenas intenciones59, sino una colección de cuentos ambientados en México, que, aun con una notable calidad, no dan la verdadera medida del talento de Aub ni lo vinculan a una temática nacional. El zopilote constituye, en el discurso de Iglesias Laguna, la evidencia más palmaria del desinterés de los autores exiliados por España; su desnacionalización, que era uno de los

\footnotetext{
56 Que pasó la censura en junio de 1964 con tres tachaduras referentes a Franco, al Papa y a los curas. Al final del informe, en el que se autorizaba la edición de la colección de cuentos, se añadía que "Max Aub, unico autor cuyo nombre se cita, es un español de destacadas ideas izquierdistas, en el exilio" [sic]. AGA 21/15159, Exp. 2247/64. Véase Aznar Soler, Manuel: "Autocensura y censura de las literaturas del exilio republicano en la España franquista: Sobre la edición en 1966 de Mis Páginas Mejores, de Max Aub”, Ínsula, 678, 2003, pp. 2-5.

${ }^{57}$ Iglesias Laguna, Antonio: "Max Aub. El zopilote y otros cuentos mexicanos", La Estafeta Literaria, 311, febrero de 1965, p. 14. Juicio que repite en Treinta años de novela española (1938-1968), ob. cit.

58 Seix Barral intentó editar la novela en 1959. Después de que cuatro lectores, confusos y sin saber muy bien qué dictaminar, la leyeran, se denegó su publicación, a pesar de que ninguno de ellos daba como única opción la prohibición de la novela. AGA (03) 50 21/12481, Exp. 3428/59. En 1967 Delos Aymá volvió a intentar editar la obra. Esta vez un único lector se encargó de realizar el informe, y se autorizó la publicación de la obra con tachaduras en cinco páginas. AGA (03) 50 21/18255, Exp. 5491/67. Véase Larraz, Fernando: "La calle Valverde, de vuelta a España", El correo de Euclides, 8, 2013, pp. 179-189.

${ }^{59}$ Las buenas intenciones había intentado importarse en 1955, siendo denegada la posibilidad de que entraran en España doscientos ejemplares de la obra, y sin que hubiera un informe de lectura (Exp. 1008/55). En 1968 la editorial Andorra trató de editar tres mil ejemplares de la novela (Exp. 4776/68): el primer lector, Pedro Borges, determinó que "A pesar de las conocidas tendencias políticas del autor y no obstante aludirse en varias ocasiones al advenimiento de la República y al Movimiento Nacional, la obra carece totalmente de toda agresividad contra el actual Régimen español. Aun más, en conjunto, la República aparece desfavorecida en las pocas y breves alusiones que se hacen de ella», y, aunque recomienda una serie de supresiones, no considera "rigurosamente necesario" que se hagan. Autoriza la edición de la novela "sin duda de ninguna clase, a pesar su denegación en 1955". El segundo lector, Iglesias Laguna, da cuenta de la calidad literaria de las obras de Aub, y recomienda "suprimir la escena final del asesinato de Agustín (pág. 137)" y "tachar lo señalado en las págs. 71, 85, 99, 104, 113 y 123 o suavizarlo un poco". $\mathrm{Al}$ final añade que "se trata de pequeños detalles cuya supresión en nada resta calidad literaria a Las buenas intenciones". Gracias a este dictamen, Las buenas intenciones no se ha vuelto a editar sin las supresiones propuestas por Iglesias Laguna.
} 
elementos clave del discurso franquista sobre el exilio intelectual. Aub publica obras en España en las que es el lugar de acogida el representado, y "hay tal autenticidad en el Méjico de Max Aub que los españoles que pululan por las páginas de El ropilote tienen menos sustancia que los nativos", frase que abunda en la postura oficial de rechazo de la españolidad de los temas de los autores expatriados, que escriben sobre españoles "opacos, grises", mientras que sus mexicanos "rezuman verosimilitud, sustancia novelística"60.

En el informe de censura que Iglesias Laguna redactó sobre Campo cerrado en 1969 afirmó, ejerciendo una vez más de crítico en vez de censor, que la obra está "maravillosamente escrita, con un lenguaje plástico, expresivo y riquísimo que le confiere categoría de obra de arte", "como es habitual en Max Aub"61. A pesar de ello —o, quizá precisamente por ello-, determina que "de autorizarse la edición popular de este libro convendría tachar lo señalado en las págs. 23, 26, 27, 29, 30-31, 40, 42, 51, 59, 84, 100, 115, 118, 141, 165-166, 188, 195 y 207-209”. El informe de Iglesias Laguna, que proponía más de veinte tachaduras, algunas de considerable extensión, era, sin embargo, mucho más generoso que el segundo dictamen, que rechazaba de pleno la publicación de Campo cerrado por ser "pretexto para hacer propaganda de las ideas izquierdistas y, especialmente, anarquistas" 62 , lo cual muestra lo poco que habían entendido la novela. Prevaleció este segundo informe y Campo cerrado permaneció inédita en España hasta 1978, año en que apareció en Alfaguara, junto con los demás Campos.

Iglesias Laguna, además de perpetuar la idea de que los escritores exiliados no regresaban a España porque no querían, reitera en varias reseñas la idea del ateísmo o agnosticismo de los republicanos españoles -que bajo el concepto nacionalcatólico de España equivalía a antiespañol- como elemento clave de interpretación de sus obras. A la hora de acercarse a la novela histórica El hombre de la cruz verde, de Segundo Serrano Poncela, que ya había leído para la censura y para la que había propuesto la autorización con tachaduras en seis páginas por "razones morales" y una por "contener una expresión sacrílega"63, explica que "los intelectuales republicanos se apasionaban por cuanto querían destruir y estudiaban afanosos a los místicos, los misioneros y los conquistadores" 64 . Ello explicaría el interés que los exiliados republicanos, según Iglesias Laguna, tenían por el tema religioso. Al abordar la problemática cristiana "ha incrementado la hondura y calidad de sus creaciones, con el beneficio consiguiente para la narrativa española". Dado que Iglesias Laguna está actuando desde su posición de crítico literario y no como censor, se ve obligado a afirmar que el juicio sobre la religiosidad de los escritores exiliados no le preocupa desde el punto de vista ético, sino estético, aunque, como indica más adelante,

también la ética sale beneficiada. Los escritores del exilio -Segundo Serrano Poncela entre ellos-, aunque examinen críticamente el catolicismo, reconocen su arraigo en las masas, su vigor tradicional, la imposibilidad de ignorarlo al novelar sobre España y los españoles. Por ende, son creyentes a su modo.

\footnotetext{
60 Iglesias Laguna, Antonio: "Max Aub. El zopilote y otros cuentos mexicanos", ob. cit., p.14.

61 AGA (03) 50 66/02664, Exp. 2050/69.

62 AGA (03) 50 66/02664, Exp. 2050/69.

63 AGA (03) 50 66/03541, Exp. 1059/69.

${ }^{64}$ Iglesias Laguna, Antonio: "El hombre de la cruz verde de Segundo Serrano Poncela", ABC, 09/07/1970, p. 115.
} 
Resuenan en estos juicios el de uno de los artículos más más primerizos y conocidos en España sobre el exilio: "La evolución espiritual de los intelectuales españoles en la emigración", cuyo autor, José Luis López Aranguren, se había centrado en defender la posibilidad de recuperar a algunos exiliados en el caso de que en su obra demuestren una evolución o conversión que era, sobre todo, de tipo religioso. Es decir, los escritores que mostraran que sus juicios políticos y religiosos, la razón de su destierro, habían cambiado. Aquellos que no habían vivido esa evolución, como Max Aub, León Felipe o Rafael Alberti, quedaban fuera del intento de diálogo que se iniciaba desde la península por mantener con ellos posturas irreconciliables. Quienes habían llamado a la reconciliación desde el principio y daban cuenta de los errores de la guerra, como Claudio Sánchez-Albornoz, también quedaban fuera de ese puente tendido desde el interior, dado que su llamamiento no se correspondía con una evolución. Los únicos que se pueden recuperar son aquellos que relativizaban la Guerra Civil y lo encontraban como un acontecimiento para el que no había que buscar culpables (López, 1953: 123-157).

En el caso de Xavier Benguerel, se suma al hecho de ser un autor exiliado el que escribiera sus obras en catalán, lengua hacia la que el políglota Iglesias Laguna no oculta sus prejuicios. En la reseña que escribe en La Estafeta Literaria sobre Gorra de plato no solo desestima al escritor exiliado, sino que lo culpa de que su obra no se haya conocido hasta entonces: "Pensemos que si Benguerel, Espriu, Arbó, Pere Quart y Pla tienen hoy un valor para los españoles cultos, ello obedece a que sus obras ya son accesibles a todos, sacadas del ámbito angosto de la lengua vernácula"65. El crítico está obviando que Benguerel había pasado su etapa de exilio traduciendo sus obras del catalán al castellano para que los exiliados no catalanohablantes pudieran acceder a ellas en editoriales extranjeras.

La adscripción de Treinta años de novela española (1938-1968) a la categoría de obra historiográfica resulta problemática, dado que, a efectos prácticos, esta monografía de Iglesias Laguna no es sino una recopilación de textos en los que el censor realiza una crítica literaria, centrándose, en vez de en los textos, en los autores que los escriben. Fernando Larraz, lo califica de "ensayo en el sentido estricto de la palabra" (Larraz, 2009: 303). Ya en la época en que salió publicada, Antonio de Zubiaurre dijo de ella que "sobra insistir en que la obra no se reduce a información de diccionario. Su necesario acento polémico, ya advertido, se matiza en aclaraciones de sumo valor"66. En efecto, para redactar la obra de Iglesias Laguna no bastaba con que el crítico conociera los nombres y obras de los autores que iba a incluir, ni que supiera agruparlos y etiquetarlos de alguna manera. Iglesias Laguna muestra haber leído a todos los escritores que aparecen en Treinta años de novela española, aunque sus juicios pocas veces nos parezcan originales y propios, sino más bien subsidiarios del discurso literario oficial, al que servía como funcionario del servicio de censura. Esto hace que el catálogo que presenta sea parcial, subjetivo y repleto de juicios personales, como dice Zubiaurre, y, por lo tanto, discutibles, sobre los autores que aparecen.

\footnotetext{
65 Iglesias Laguna, Antonio: "Mi voluntad se ha muerto", La Estafeta Literaria, 415, marzo de 1969, p. 113.

${ }^{66}$ De Zubiaurre, Antonio: "Una lección de historia literaria. Anotaciones críticas a Treinta años de novela española", La Estafeta Literaria, octubre de 1969, p. 9.
} 
Expresa Iglesias Laguna en el "Prólogo" del libro que "a los novelistas del exilio no se les estudia aquí debidamente. No por ignorancia o menosprecio de su obra, sino por necesidad de enfoque"(Iglesias Laguna, 1970: 19) 67; y promete un estudio en profundidad de los exiliados que nunca llegó a realizar antes de su muerte, tres años más tarde. Sin embargo, realiza múltiples alusiones a escritores exiliados, a los que agrupa y contrapone a los narradores que escriben y publican en el interior.

En las reseñas críticas, Iglesias Laguna insistía en que los exiliados escribían principalmente sobre temas americanos desde una perspectiva extraña a la realidad nacional. Por el contrario, cuando recibe el Premio Nacional de Literatura Emilia Pardo Bazán (1969) por Treinta años de novela española, el autor resume para el periódico Ya la postura adoptada en el volumen: "la novela de los españoles en el exilio es completamente novela española como la que más. Aparte de que los exiliados nunca han dejado de hablar de España. Muy pocas veces se han ocupado de los países en que viven o vivían; lo que ocurre es que la temática era tan grande y las dimensiones editoriales tan limitadas que no podía hablar de todo. Dedicaré un libro a este tema"(Iglesias Laguna, 1970: 19-20). En este juicio y en su incumplido propósito de estudiar la obra de los exiliados late la necesidad de anular la anomalía que suponía una literatura española fuera de España: normalizar la situación negando que estos autores estuvieran sometidos a un ostracismo al que, indudablemente, había cooperado Iglesias Laguna

Sí reincide Iglesias Laguna en la afirmación de que los escritores exiliados no son conocidos en España debido al alejamiento geográfico, las dificultades editoriales y los estragos psicológicos derivados de la derrota militar, que causan irremediablemente un alejamiento de la realidad nacional, un desconcierto ante los derroteros de la literatura moderna y un menoscabo de las calidades literarias. El exilio provoca una especie de patología en el expatriado, que hace que viva en un "doloroso sentir"(Iglesias Laguna, 1970: 20) y que identifique a España "con la de sus sueños o se refugiarán en un ayer periclitado [...] anclándose en un presente suyo que hoy es pura historia para los españoles de España” (Iglesias Laguna, 1970: 28). Los autores exiliados, que han viajado, conocido otras ciudades y culturas, lejos de haber ensanchado su perspectiva temática e intelectual (Larraz, 2009: 302), viven obsesionados, por lo que, dice Iglesias Laguna, "necesitarán mucho tiempo para sobreponerse al trauma de la derrota, para darse cuenta de que, al cabo de casi treinta años, el pasado importa menos que el presente”(Iglesias Laguna, 1970: 71).

A pesar de ello, los lectores españoles se han interesado por la obra del exilio, que "con el tiempo se edita en la propia España”(Iglesias Laguna, 1970: 29) sin que exista reciprocidad. Los autores exiliados "son conocidos en España, e incluso editados, mientras que en América desconocen a la mayoría de los novelistas españoles de hoy, y no digamos a la juventud"(Iglesias Laguna, 1970: 70), escribe Iglesias Laguna falseando de nuevo la realidad. Los exiliados, por tanto, se encontraban ya en igualdad de condiciones para "competir" con los autores del interior, más

\footnotetext{
${ }^{67}$ Curiosamente, casi las mismas palabras serán utilizadas para explicar la injustificable omisión de la narrativa del exilio por José María Martínez Cachero, pocos años después, en su propia historia literaria, que a diferencia de la de Iglesias Laguna tuvo muchas reediciones, revisiones y ampliaciones. Las palabras concretas de Martínez Cachero en su introducción fueron: "la novelística del exilio no es objeto de estudio dentro de este estudio, y quiero advertir que no por ignorancia o menosprecio" (Martínez Cachero, José María: La novela española entre 1939 y 1969. Historia de una aventura. Madrid, Castalia, 1973, p. 7).
} 
conocidos y aceptados por una cuestión de talento, actualidad y alcance intelectual ante la crítica y el público.

Mención aparte merece la manera en que trata a los escritores exiliados cuando, en un capítulo de siete páginas titulado "La voz del exilio", intenta dar algunas pinceladas de la narrativa de escritores exiliados. Menosprecia los textos narrativos sobre la guerra civil de Sender, Arconada y Aub porque "estos no anduvieron por el frente" -apunte, por cierto, falaz en los tres casos y particularmente en el de Sender, que combatió en el Quinto Regimiento-, y aprovecha para compararlos con Hemingway, a quien desprecia en esta obra de crítica literaria por razones puramente literarias; a saber: sus aventuras amorosas entre 1950 y 1955 (Iglesias Laguna, 1970: 86), de las que al parecer no daba cuenta su biógrafo y amigo José Luis Castillo Puche. Agrupa a los autores y autoras del exilio en cuatro epígrafes siguiendo unos criterios dispares: por una parte se encuentran las valoraciones a Sender, Arconada y Aub, separada del estudio de "los de Méjico y Chile y alguno más", a los que sigue el estudio de "Benavides, Massip [sic], De Pedro, etc." y de los exiliados "soñadores y recalcitrantes"(Iglesias Laguna, 1970: 83-92).

$\mathrm{Al}$ igual que en el caso de las autores del interior, también aquí es obvia la minusvaloración de la obra de escritoras exiliadas. De todos los nombres que podía reflejar, en su obra selecciona tres: Luisa Carnés, Isabel de Palencia y María Teresa León. No menciona a Rosa Chacel, que ya había publicado la mayor parte de su obra. A todas ellas les dedica en conjunto un párrafo de once líneas en las que no valora su obra completa, no da cuenta de su valor literario y testimonial ni de la importancia de su narrativa, sino que se limita a criticar la calidad literaria de Luisa Carnés, el tono amargo de Isabel de Palencia y la poca veracidad de las obras de María Teresa León, sin explicar a qué se refiere con ello ni de qué trata su obra (Iglesias Laguna, 1970: 87).

“La voz del exilio se debilita paulatinamente”(Iglesias Laguna, 1970: 90), concluye Iglesias Laguna. La prueba, según él, es que ya está en España Alfonso Camín, que escribió unos poemas en la época de la España republicana que le "brotaron de la pluma «en el fragor de la pelea»", pero que ahora ya son accesibles al público español, porque es "agua pasada"(Iglesias Laguna, 1970: 90). Sin embargo, los exiliados republicanos no han pasado página. Y son estos los que forman el grupo de "soñadores y recalcitrantes": aquellos que se ocupan de los años del hambre y el bloqueo tras haber "emigrado" en la posguerra (cita aquí a Enrique Azcoaga y Manuel de Pedrolo) o aquellos que escriben en otras lenguas, que se han naturalizado como escritores fuera de España y "ni aun así olvidarán el trienio trágico, y todavía menos si, por azar de las circunstancias, retorna pasajeramente a la Península en los años difíciles”(Iglesias Laguna, 1970: 91) (como sucede, según Iglesias Laguna, con Michel del Castillo y Jorge Semprún).

No puede dejar de destacar a los exiliados que publican en España, como Francisco Ayala, Ramón J. Sender, que además colaboran en algunas revistas españolas. Iglesias Laguna reincide en la falacia de que los exiliados son conocidos y valorados en el interior, aunque la narrativa de los autores exiliados está "supervalorada en estos momentos, harán falta unos años para que se la juzgue sin ditirambos”(Iglesias Laguna, 1970: 91). 


\section{CONCLUSIONES}

Antonio Iglesias Laguna no dirime entre su actividad como crítico literario y como censor, sino que utiliza su autoridad como reseñista para instituir un discurso de género, de nación y de lengua. Así, en un primer grado distingue la escritura de mujeres de la de los hombres. La voluntad de relegar al espacio doméstico a las mujeres llevado a cabo por el franquismo queda reflejada en la manera que tiene de acercarse a ellas tanto en sus informes y reseñas como en Treinta años de novela española (1938-1968). Minusvalora la escritura de las autoras, trata de reducir su espectro de recepción y las tilda de aprendices de escritura en vez de escritoras. Su menosprecio es mayor cuando se trata de escritoras exiliadas, de quienes no escribe ninguna reseña ni las trata mínimamente en su ensayo.

También son relegados a posiciones secundarias los autores exiliados, los republicanos y los hispanoamericanos. Por razones estrictamente políticas y nunca reconocidas, la crítica oficial no quiere que estos escritores sean leídos ni mucho menos canonizados e Iglesias Laguna utiliza sus reseñas para deslegitimarlos y rebajar la calidad de su obra, a pesar del éxito que en aquellos años tenían algunos de ellos. Debido al pretendido aperturismo político del tardofranquismo, la censura que realiza Iglesias Laguna tiene que estar matizada, disfrazada de crítica literaria, abusando de su autoridad como crítico y pervirtiéndola para diluir valoraciones perniciosas sobre autores no basadas en la calidad literaria de la obra, sino en juicios políticos y religiosos. En esta fase de la represión cultural iniciada hacia 1962, más que de prohibir, se trata de encubrir la imposición a través de la mistificación, dando apariencia de normalidad a lo que no la tiene.

Este uso de la crítica literaria con propósitos políticos en un sentido estricto, en este caso a favor del régimen, fue visto por varios críticos. Rafael Conte, al hablar de Treinta años de novela española (1938-1968) en las páginas de Informaciones, señalaba que "al emplear en sus valoraciones principios de carácter doctrinal con mucha frecuencia, o juicios de valor más políticos que literarios, la sociología del libro se debilita notablemente" 68 . Al analizar la misma obra, Fernando Álvarez Palacios expresó que:

si se tratara de un caso aislado, el suceso no vendría a tener mayor importancia. Pero ya
que este pensamiento puede tener estrecha concatenación con el de otros plumíferos,
denominados a veces, para entendernos, como críticos oficiales, entonces quizás fuera
conveniente expresar algunas consideraciones respecto al especial sentido histórico-crítico
de Iglesias Laguna, que por su caracterizada posición hasta su muerte, puede, entiendo
que perfectamente, representar al más conservador e inmovilista grupo de críticos de la
derecha (Álvarez, 1975: 114)

Iglesias Laguna se refiere casi en exclusiva, tanto en Treinta años de novela española como en sus críticas literarias, a los novelistas que escriben en lengua castellana, distinguiendo entre los españoles y los hispanoamericanos, a quienes trata de invisibilizar mediante su desprecio generalizado al boom y afirmando la superioridad de los autores españoles del interior. No se pronuncia sobre el hecho de que las novelas que se conocían de escritores exiliados en España nunca eran sus mejores obras y desestima tanto el valor de los narradores exiliados, acusándolos de estar resentidos contra España y de haber perdido el rigor intelectual y la lucidez como

68 Conte, Rafael: “Un torrente narrativo”, Informaciones de las Artes y las Letras, 51, 19 de junio de 1969, p. 3. 
consecuencia de las vicisitudes de su biografía, como el de las mujeres, cuya escritura está siempre supeditada a la masculina.

Sin embargo, no es todo política en los juicios de Iglesias Laguna. El crítico es oportunista, y utiliza también sus escritos para mejorar sus relaciones con escritores influyentes. Así, el trato de favor que merecen en público Camilo José Cela y Francisco Umbral no se debe tanto a la calidad literaria de sus obras como a sus contactos con las altas esferas políticas y culturales del país, de los que él mismo se vio beneficiado.

Todo ello hace que en Iglesias Laguna se encarne la figura del crítico oficial, aneja a la del intelectual orgánico que definió Antonio Gramsci, y que en un contexto dictatorial viola la autonomía del campo literario y manipula conscientemente el lenguaje crítico hasta convertirlo en instrumento legitimador del estado de cosas. La crítica, tal como la ejerce Iglesias Laguna, no es un ejercicio de discusión pública, sino de defensa de posiciones cerradas y dogmáticas a las que se debe plegar el lector. En este sentido, censurar y criticar no pertenecen a universos discursivos ajenos salvo por minúsculos atributos formales, sino que, como decíamos al principio de este trabajo, sirven a un mismo fin.

La actuación de Iglesias Laguna, tal como la hemos analizado en las páginas anteriores, apoya la idea de que la imposición de un régimen de represión intelectual conllevó que en la conciencia de determinados agentes no se distinguiera entre las funciones de la censura y la crítica literaria. El modo de proceder de este crítico-censor no era marginal; había un sector de la crítica oficial para quienes el valor la literatura no era de naturaleza intelectual o estética, sino que residía en su capacidad para influir en la mentalidad de los lectores. Por ello, crítica y censura eran procesos muy similares que debían implicar control, discriminación, reprobación y, finalmente, intervención. Ello potenció la actuación de la censura e implicó la instauración de un canon parcial y falseado que excluyera a las mujeres que no escribían como tales según los arquetipos patriarcales, a los escritores exiliados y a los narradores hispanoamericanos, resaltando la importancia de los autores del interior que no pusieran en tela de juicio la ortodoxia al Régimen. La contaminación entre el discurso político y literario que siempre ha habido se vio por tanto potenciada durante el franquismo, y quizás continuada durante la transición hasta que la influencia de los críticos literarios decayó y perdieron el papel influyente que habían tenido en la creación del canon literario. 
BIBLIOGRAFÍA

ABELLÁN, Manuel L. "Sobre censura. Algunos aspectos marginales". Cuadernos del Ruedo Ibérico 49-50 (1976): 125-139.

ABellán, Manuel L. (1980). Censura y creación literaria en España (1939-1976). Barcelona: Península.

ABELLÁN, Manuel L. "Censura y autocensura en la producción literaria española”. Nuevo Hispanismo 1 (1982): 169-180.

ABellán, Manuel L. "Fenómeno censorio y represión literaria”. Diálogos hispánicos de Ámsterdam 5 (1987): 5-25.

Álvarez Palacios, Fernando (1975). Novela y cultura española de postguerra. Madrid: Cuadernos para el Diálogo.

Canavaggio, Jean (1995). Historia de la literatura española: tomo VI, El Siglo xx. Barcelona: Ariel.

Conde PeÑalosa, Raquel (2004). La novela femenina de posguerra (1940-1960). Madrid: Pliegos.

DíAZ, Elías (1983). Pensamiento español en la era de Franco. 1939-1975. Madrid: Tecnos.

Iglesias Laguna, Antonio. (1970). Treinta años de novela española (1938-1968). Madrid: Prensa Española.

Iglesias LagunA, Antonio. (1972). Literatura de España día a día (1970-1971). Madrid: Editora Nacional.

LARraz, Fernando (2009). El monopolio de la palabra. El exilio intelectual en la España franquista. Madrid: Biblioteca Nueva.

LARRAZ, Fernando (2014). Letricidio Español, censura y novela durante el franquismo, Gijón: Trea, Gijón.

LARraz, Fernando. "Censura, exilio y canon literario". Historia Actual Online 42 (1) (2017).

LÓPEZ ArAnguren, José Luis. "La evolución espiritual de los intelectuales españoles en la emigración". Cuadernos Hispanoamericanos 38 (1953): 123-157.

Montejo Gurruchaga, Lucía (2010). Discurso de autora: género y censura en la narrativa española de posguerra. Madrid: UNED.

Moradiellos, Enrique (2000). La España de Franco (1939-1975). Politica y sociedad. Madrid: Sintesis.

OrgAZ, Manuel et al. "Ante la muerte de Antonio Iglesias Laguna, siete notas para una biografía”. La Estafeta Literaria 505 (1972).

RUIZ BAUTISTA, Eduardo (2005). Los señores del libro: propagandistas, censores y bibliotecarios en el primer franquismo. Gijón: Trea.

RUIZ BAUTISTA, Eduardo (coord.) (2008). Tiempo de censura. La represión editorial durante el franquismo. Gijón: Trea. 
Umbral, Francisco (1999). Trilogía de Madrid. Madrid: Planeta.

YNDURÁIn, Francisco. “Resentimiento español. Arturo Barea”. Arbor 24 (1953): 73-79. 